\title{
First Bush budget set to favour life sciences
}

\section{Matthew Davis, Washington}

The first budget proposal of US president George W. Bush is expected to seek billions of additional dollars for biomedical research - but precious little for any other scientific programmes.

Sources familiar with the plan, which will be released early next week, say Bush will ask for a $\$ 3$ billion (15\%) boost for the National Institutes of Health (NIH), making good on his campaign promise to carry on the effort begun three years ago to double the agency's budget by 2003 .

But Bush is likely to seek an increase of just $1-2 \%$ for the National Science Foundation (NSF) - the main backer of non-biomedical university research in the United States which last year got a $14 \%$ increase. He is expected to maintain funding for science programmes at the Department of Energy, which supports most US physics, at current levels and may slash the US Geological Survey's $\$ 885$ million budget by $20 \%$ or more.

A Republican congressional official familiar with the Bush administration strategy says that the numbers do not reflect any hostility towards the physical sciences. Rather, the embryonic administration, which has had to frame its budget before many of its senior positions have been filled, is trying to fulfil specific campaign promises. That means increasing spending for education, the NIH and perhaps defence, while controlling the overall budget sufficiently to allow for a promised cut in income tax.

Research administrators in the physical sciences are alarmed at the possible impact of this strategy on their budgets. They fear that, despite their recent efforts to make a case for a fairer balance between disciplines, the outcome will deepen what they see as an imbalance in favour of biomedical research.

At a recent meeting with senior White House budget official Mitch Daniels, Sherwood Boehlert (Republican, New York), who chairs the House Science Committee, complained about Bush's meagre allocations for research at the NSF, NASA and other agencies. According to one source at the meeting, Daniels displayed a detailed knowledge of the various science programmes. But he left a clear impression that Bush's proposed spending increases will remain tightly focused on initiatives, such as doubling the NIH budget, that were the subject of campaign promises.

Some NIH advocates are nervous that the agency's unprecedented expansion will come into direct conflict with other programmes for the first time. They fear that if other health and social-assistance programmes are cut to allow the NIH to grow, the broad coalition that has previously supported the agency in Congress may fracture.

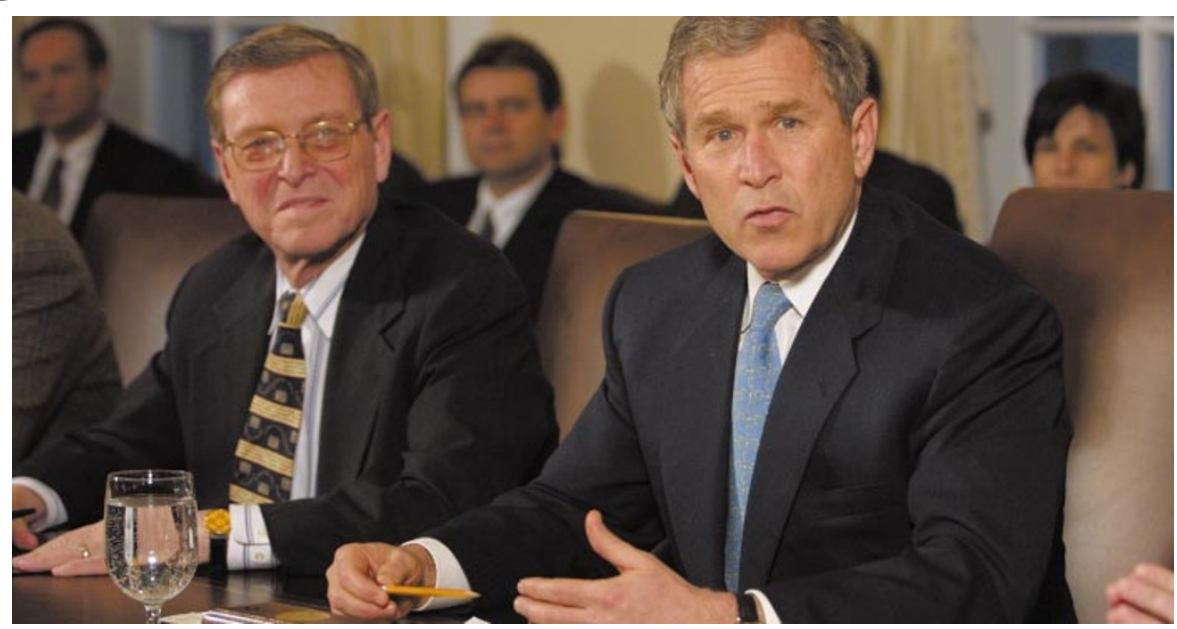

Senate budget chair Pete Domenici (left) and others in Congress may augment Bush's spending plans.

But last week NIH supporters drummed up support for a non-binding resolution introduced by Senator Arlen Specter (Republican, Pennsylvania) and Senator Tom Harkin (Democrat, Iowa) that would put the Senate on record as supporting an extra $\$ 3.4$ billion for the NIH in 2002.

With Specter and Harkin leading the charge, Congress has handed the NIH an additional $\$ 6.7$ billion over the past three years, with no other programmes appearing to have suffered as a result. That was because a mounting budget allowed President Bill Clinton and the Congress to engage in a succession of spending sprees that satisfied almost every constituency.

Things could be different this year. Budget experts on Capitol Hill say that, with Republicans controlling both Congress and the White House, and tax cuts and a slowing economy reducing the surplus, the days of unbridled appropriations - even for a Republican favourite like the NIH - may be over.

And at less fashionable agencies such as the Department of Energy, which was initially told by the new administration to prepare for a $\$ 1$ billion reduction in its $\$ 18$ billion budget, administrators fear that merely maintaining current funding could lead to stagnation for the physical sciences. Their best hope is that Congress, which will consider the Bush request this summer before passing a final budget by October, will be persuaded to augment the Bush proposal.

\section{Farming accused of eco-damage}

Corie Lok, Washington

The growing intensity of agriculture around the world is destroying soil quality, wasting water, demolishing forests and adding to greenhouse-gas emissions, according to a report by the International Food Policy Research Institute (IFPRI) and the World Resources Institute (WRI).

The Pilot Analysis of Global Ecosystems: Agroecosystems is billed by its authors as the first comprehensive audit of agriculture's global ecological impact. It argues that as much as four-fifths of the world's farm land is being degraded by agricultural effects such as erosion, nutrient depletion, acidification and loss of organic matter.

The audit makes a good case for more investment in agricultural research, especially in the developing world, says Ian Johnson, chair of the Consultative Group on International Agricultural Research and a vice-president of the World Bank. The bank is expected to use the report in its own forthcoming assessment of global ecosystems. Agricultural science and technology, including genetically modified crops and plant breeding, are critical to raising food production while protecting natural resources, adds Robert Thompson, director of rural development at the bank.

The report says that farmers withdraw $70 \%$ of the world's fresh water supply for irrigation, but more than half of this is lost through evaporation. Farm land has grown by around 130,000 square kilometres a year over the past 20 years, mostly at the expense of forests and grasslands, it says, and farming is also encroaching on many national parks and other protected areas.

The audit also finds that agriculture is the largest source of methane - a potent greenhouse gas - from human activities, responsible for $44 \%$ of all emissions. And it calls for more investment in the science of ecosystem monitoring.

www.ifpri.org 